Indonesian Journal of EFL and Linguistics

Vol. 4 No. 2, 2019

eISSN: 2503-4197, pISSN: 2527-5070

www. indonesian-efl-journal.org

\title{
The Challenges of Language Learning of the Study-Abroad Students of English Language Department of Islamic Higher Education in Kalimantan
}

\author{
Umar Fauzan \\ State Islamic Institute of Samarinda, Indonesia \\ e-mail: umar.fauzan@iain-samarinda.ac.id \\ Nadia \\ State Islamic Institute of Samarinda, Indonesia \\ e-mail: nasya8087@gmail.com
}

\begin{abstract}
:
The purpose of this study is to uncover: 1) How foreign students believe in learning English at Islamic higher education in Kalimantan, 2) The experience of foreign students in learning English at Islamic higher education in Kalimantan, 3) The challenges of foreign students in learning English at Islamic higher education in Kalimantan. This qualitative phenomenological research was to disclose the phenomenon of the entry of foreign students to Kalimantan. The main participants of the study were foreign students and English lecturers of state Islamic institute of Samarinda, state Islamic institute of Palangkaraya, and state Islamic university of Antasari. Meanwhile, the secondary participants of the study were foreign students and English lecturers from the state Islamic institute of Pontianak. The instruments were interviews, documentation, and observation. Analysis of research data used a model from Miles and Huberman consisting of data collection, data reduction, data presentation, and drawing conclusions. There are three important findings of this study. Firstly, foreign students believe in learning English at Islamic higher education in Kalimantan. They declared that the curriculum is appropriate, carried out by a good process, facilitated by adequate learning facilities, and implemented by competent teachers with varied learning methods. They were also assured to get the extra benefit of not only learning English but also learning Islamic material.
\end{abstract} Indonesian Journal of EFL and Linguistics, 4(2), 2019 
Secondly, regarding to the experience of foreign students, there are two main things as our conclusion, namely: language learning benefit and socio-cultural benefit. In the context of learning English, they learned English material and felt more confident in speaking English. Meanwhile, from the socio-cultural aspect, foreign students at Islamic higher education in Kalimantan enhance their life experiences by learning the social life of the Indonesian people which enrich their life experiences. Thirdly, the challenges they faced were independent living, increasing selfconfidence, mastering learning material, improving English speaking skills, and adapting to the environment, such as: food, language, or culture.

Keywords: Islamic higher education, language learning beliefs, study-abroad experiences

\section{INTRODUCTION}

English education study programs at Islamic higher education in Kalimantan accept students not only from Kalimantan but also from neighboring countries. Some students, who are coming from Malaysia, Thailand, and Philippines, take English study programs at Islamic Higher Educations in East Kalimantan, South Kalimantan, or Central Kalimantan. The easy access to information and transportation makes foreign students register to English study programs at Islamic Higher Education in Kalimantan.

The indication of English mastery can be seen from the ability of English learners in mastering four English skills, namely: reading, listening, writing, and speaking. Every student who chooses the English education study program is expected to learn those four skills. Of the four skills, writing and speaking are benchmarks of student's success in learning English. This is because writing and speaking are categorized as productive skills where English learners are required to be able to produce written language in the form of writing or produce English in the form of speaking. Therefore, if an English learner is able to express ideas or thoughts in written form or in oral form, he/she is categorized mastering English.

To succeed in learning English, there are several determining factors, namely: belief, attitude, motivation, and anxiety. Amongst them, belief is supposed to be a very determining factor to get success in learning English. We will definitely be able to do something if we have self-assurance first. By having strong beliefs, it can be achieved what is believed. Therefore, the students must be confident in mastering English, so that later in the learning process it becomes easy to stay strong and keep trying when facing difficulties.

Confidence becomes an important key and encourages success in learning English. Many students who become foreign students are more confident and grow selfpossessed when studying abroad (Tanaka \& Ellis, 2003). The results of Kaypak \& 
Ortaçtepe's (2014) research show that learning foreign languages abroad has a significant influence on language development. Studying abroad tends to change the focus from language accuracy to the right use of language. In other words, it is not merely focused on the grammatical aspect but it is precise and effective when language is used. Another study on the effect of being a foreign student in language learning was also conducted by Sato (2014) who found that foreign students became more active in using English in their daily interactions with local students.

Another benefit of the presence of foreign students in the context of language learning is what Morreale (2011) wrote in his dissertation entitled: "The Relationship between Study Abroad and Motivation, Attitude and Anxiety in University Students Learning A Foreign Language". Morreale's dissertation revealed that the motivation of local students in classes was higher to learn foreign languages due to the existence of foreign students than those who do not have foreign students.

Being a foreign student gives a lot of valuable experience. Getting to know the culture and adapting is one of them. Different cultures will certainly provide their own challenges and uniqueness that they must face. Different habits make foreign students more sensitive and appreciate differences. As a result, a stronger friendship and brotherhood unite them. The students are required to adapt and adjust to the new environment in which they live.

The experience of differences in situation and culture demands the foreign students to be more active in their new environment, including in the learning environment in the English class. There will be obstacles to learning English if they tend to be passive in the classroom. Foreign students who do not understand the language in the new place where they live, definitely, will be a problem in themselves. Daily activities will be disrupted when unable to convey or receive messages to the interlocutors encountered. Thus, the activeness of foreign students is important to overcome the obstacles in communicating both inside and outside the classroom.

English language study programs at State Islamic Institute of Samarinda (East Kalimantan), State Islamic Institute of Palangkaraya (Central Kalimantan), and at Antasari State Islamic University (South Kalimantan) open access for the entry of foreign students from various countries to take majoring in English education. Starting in 2015, foreign students from Malaysia, Thailand, Philippines, and Turkey came and studied at the Islamic Higher Educations in Kalimantan.

The formulation of the problem to be investigated in this study is as follows:

1. How is the foreign students' belief towards learning English in English language study programs at Islamic Higher Education in East Kalimantan, South Kalimantan, and Central Kalimantan?

2. What experiences do foreign students gain in learning English in English education courses at Islamic Higher Education in East Kalimantan, South Kalimantan, and Central Kalimantan? 
Umar Fauzan and Nadia

3. What are the challenges faced by foreign students in learning English in English language study programs at Islamic Higher Education in East Kalimantan, South Kalimantan and Central Kalimantan?

\section{LITERATURE REVIEW}

The era of the industrial revolution 4.0 thinly eroded national borders. The flow of information and transportation is easy in this era. All aspects of life become globalized. All products and services from abroad easily enter Indonesia or vice versa, all products and services from Indonesia easily exported abroad, including in educational context. Indonesia opens access and participates the current globalization of education. Higher education institutions from abroad as well as foreign students will enter Indonesia. Meanwhile, there are also many Indonesian students study abroad as well. So, the internationalization of education including English education is inevitable.

Similar to English regular students in general, foreign students also emphasize learning skills in four English skills when learning English; reading, listening, writing, and speaking. To succeed in mastering these four skills, the belief factor is the main element in learning English. Kaymakamoğlu \& Atmaca (2016) said, "Learner beliefs can be defined as the perception of people towards the learning situation that they are in, and it is also believed that those learner beliefs affect the actual performance of the people in the area that the learning takes place."

The belief factor becomes very important to consider either the beliefs of lecturers who teach English or the beliefs of students who learn English. Abdi \& Asadi (2015) said, "Teachers' beliefs influence what they do in the classroom, their practice, their attitude, and their students' belief. Students' beliefs affect their motivation, attitude, achievement, proficiency, anxiety, success, behavior and language learning strategy use." On the other hand, Altan (2006) revealed, "Beliefs are a central construct in every discipline which deals with human behavior and learning. Teachers' beliefs influence their consciousness, teaching attitude, teaching methods, and teaching policies. Teachers' beliefs also strongly influence teaching behavior and, finally, learners' development."

\section{RESEARCH METHODOLOGY}

This qualitative phenomenological research tries to explain the phenomenon of the entry of foreign students into Indonesia and majoring in English education in Islamic Higher Education in Kalimantan. This study tries to uncover: 1) how foreign students' belief in learning English in English education study programs in Islamic Higher Educations in Kalimantan, 2) the experience of foreign students in learning English in a language education study program English in Islamic Higher Education in Kalimantan, and 3) the challenges of foreign students in learning English in English study program in Islamic Higher Education in Kalimantan. 
The primary participants of this research were students who attended English education in Islamic Higher Education in three provinces in Kalimantan, namely: IAIN Samarinda (East Kalimantan), IAIN Palangkaraya (Central Kalimantan), and UIN Antasari (South Kalimantan). Other participants in this study were English lecturers who taught at IAIN Samarinda, IAIN Palangkaraya, UIN Antasari. The secondary participants were foreign students and English lecturers from IAIN Pontianak. This is because when conducting research at IAIN Pontianak, there is no English language education study program. However, because IAIN Pontianak also has foreign students, data retrieval is still carried out there to add or fit up the research data from IAIN Samarinda, IAIN Palangkaraya, UIN Antasari.

The researcher brought several instruments, including: interviews, documentation, and observation. Interviews were conducted by visiting English Language Study Programs in Islamic Higher Education in three provinces in Kalimantan. The researcher interviewed foreign students studying at IAIN Samarinda, IAIN Palangkaraya, UIN Antasari and also lecturers who taught English in the three universities above. Documentation is an instrument model that is carried out by collecting and analyzing all documentation owned by the English education study program at IAIN Samarinda, Palangkaraya IAIN, and UIN Antasari. The documents referred to include: syllabus, certificates, modules, guidebooks, certificates of merit, and others. Another instrument used in this study is observation. Observations were made to look directly into the entire field associated with data related to this study.

The data in this study were analyzed using data analysis from the Miles \& Huberman (1994) model which according to them the qualitative data analysis was carried out interactively which lasted continuously until the data-saturated. Data saturation means that data is considered complete and even though data is taken repeatedly the results will remain the same. Analysis of research data in this study using models from Miles and Huberman consists of: data collection, data reduction, data presentation, and drawing conclusions.

\section{FINDINGS}

The purpose of this study is to uncover three things, namely: 1) The foreign students' belief toward learning English in English language study programs at Islamic Higher Education in East Kalimantan, South Kalimantan and Central Kalimantan, 2) Experience of foreign students in learning English in English language study programs at Islamic Higher Education in East Kalimantan, South Kalimantan, and Central Kalimantan, and 3) The challenges faced by foreign students in learning English in English language study programs at Islamic Higher Education in East Kalimantan, South Kalimantan and Central Kalimantan.

\subsection{Interview Result}

To collect data, the researcher interviewed the students who come from abroad and English lecturers. Interviews to students of UIN Antasari were held on April 14-16, 
2019 while to students of IAIN Samarinda the interview was conducted on April 18 - May 18, 2019, and to students of IAIN Pontianak the interview was taken on May 19-21, 2019, and the last interview was addressed to students of IAIN Palangkaraya on June 23-25, 2019.

The results of interviews about the reasons and the belief for choosing Indonesia as the place to continue their studies in an English language study program in Kalimantan showed that there were several reasons for them to choose Indonesia, including the quality of education, close location as a neighboring country, finding experience studying abroad, curiosity about cultural and language richness in Indonesia.

Student E reasoned:

"In Indonesia, there are many institutes available, so I have many choices. And students are very brave in the class. There is also a lot of experience and good culture I found in Indonesia that I can bring to use in Thailand."

Student G argued:

"I want to find a broader experience and I also want to see the atmosphere and conditions here"

Student K stated:

"In my opinion, Indonesia has similarities with Thailand in some cases. Maybe it's because we're in same Asian country. So even in language and culture, it doesn't differ so much."

Student K asserted:

"If I fail in my course, it is not because of the poor quality of education in Indonesia but it may be because I have not put much effort into learning."

When the researcher asked about the advantages of education in Indonesia, the majority of respondents believed that education in Indonesia (Kalimantan) is excellent because every aspect of general education contained Islamic education that is rarely found elsewhere. So that, the foreign students not only learned English but also learned Islamic material. Another advantage is the low cost of living in Indonesia and the diversity of tribes, languages, and cultures in Indonesia.

Student A stated:

"Education with Islamic characteristics is rare in Thailand. So, not only study English, we are also studying Islam. The Islamic course is an advantage of education in Indonesia." 
Student B opined:

"The advantage is that English lectures in Indonesia are also given Islamic lessons. If I study English in Turkey, I will only get lessons about English whereas here English students are also required to study Islamic material. In Turkey, there isn't. That's an advantage here."

Student C declared:

"Because in Indonesia, the cost of living is not very high, and can know the tribes of Indonesian life."

Student E uttered:

"One of the strengths is that I can learn many languages and many cultures. And students will be braver for questions and answers in class."

Student F explained:

"I think with my study in Indonesia I can utilize the knowledge I gained in Malaysia. In addition, Indonesia has a university that is easily accessible to me based on where I live, which is located between the borders of two countries."

Student H said:

"My main strengths in learning here are that I can learn Indonesian and can understand the culture here, and the drawback is that I cannot focus because there are many tribes and many languages."

Student I believed:

"Living cost in Indonesia is cheaper than in other countries. Its benefits can get to know Indonesian people. Indonesian people are very kind and friendly. I am amazed that they are brave Indonesians."

Student J uttered:

"I am studying in Indonesia because this country is a very good religion and the campus is also Islamic nuance. Thus, even though we choose the English major but we can also get religious lectures. Those are the advantages of studying in Indonesia, mostly Islamic campuses."

Student K added"

"The advantage is that I may know about culture in Indonesia. Because in Indonesia there are many tribes, many religions, and there are also many cultures they practice." 
Regarding the education curriculum in Indonesia, the majority of respondents believe that the English language curriculum in Indonesia is good (Respondent C) where the curriculum provided is appropriate with the needs of the students (Respondent $\mathrm{H}$ ), even there is also respondent who claim the English language curriculum in Indonesia is better than Thailand (Respondent D). In addition, there was also respondent who criticized (Respondent I) where the curriculum was good, but in the implementation, it needed to be even better.

For the lecture method applied in teaching English in Kalimantan, the majority of respondents raised their answers if the English learning method was presented with a varied method.

Student A expressed:

"English lecturers use varied English teaching methods, such as: conversations, games, speeches, debates, discussions, etc."

Student B opined:

"For 4 skills, until now all methods have varied. Almost in all subjects, we use English. We learn TOEFL and IELTS in listening class, learning skimming and scanning in reading class, learn how to write essays, paragraphs in writing class, and in speaking class, we do many activities that are learning to speak spontaneously, create conversation, play drama, speech, and debate."

Student H certified:

"The method used is good because it makes it easier for students to quickly understand."

In general, the learning process according to students studying in Kalimantan is good with a variety of methods (Respondent B), lecturers provide opportunities for students to practice in English (Respondent I), and appropriate with the steps of learning cited in the curriculum (Respondents $H$ ). In addition, Respondent $\mathrm{D}$ suggests to foreigners that they need to learn Indonesian properly as the Indonesian language might be used in the English learning process. As a result, they will understand the entire lectures during the learning process.

Regarding the evaluation of learning, the response to this question is generally answered with "Good". As an example of the response stated by them is as follows.

Student A argued:

"Evaluation is suitable for the subjects taught, for example writing with a writing test, speaking by appealing to speak English, reading by evaluating reading comprehension, listening by asking to understand listening material." 
Student B responded:

"For listening, evaluation is carried out by making instructions listening to the listening material which carried out using TOEFL and IELTS tests. For speaking, the instructions are in the form of speaking English such as spontaneous drama plays, given situations and play spontaneously."

When they are asked about facilities, the majorities of respondents were satisfied and agree that the facilities in Kalimantan are good and complete. Although there are those who argue that it is necessary to increase learning facilities like providing air conditioners in each classroom. They also add another suggestion that English education study programs should present native speakers.

What is a valuable experience being the next question that produces many interesting findings. They responded that the valuable experience when studying in Indonesia was at first there were obstacles in Indonesian or regional languages in Kalimantan, then, they gained additional language acquisition, had more Indonesian friends who were friendly and helpful, increased knowledge and life experience, and especially in the context of learning English they felt more confident in speaking English.

Student B believed:

"Many valuable experiences, from the first time until now always feel valued and respected. Indonesian people including friends and lecturers are very friendly and really appreciate others. They are also helpful."

Student E expressed:

"Before I went to college in Indonesia I was a person who did not dare to ask questions and answer (Q\&A) but when I was here I became bolder than before."

Student F explained:

"I get a variety of different activities from where I come from. Especially from the experience of organizations in Indonesia that feels rather unique and crowded."

Student G emphasized:

"Many experiences that I got from here such as being able to increase courage in learning, for example, I learned how to dare to speak in front of the class or ask questions in class and others." 
Umar Fauzan and Nadia

Student I stated:

"A very deep experience entered my soul is people here are bolder. We are lack of confidence. They are Indonesian, even though they are wrong, they are not afraid. They dare to come to the front of the class. I'm amazed by their manner like this."

Student L asserted:

"Valuable experience is the ability to write. Have selected experience; representing the writing competition at Gajah Mada University. Then, I get an offer to take a Master's Degree at Gajah Mada University. It such a great opportunity to be more advanced."

Almost all foreign students who study English in Kalimantan confront some different difficulties, namely the difficulty of Indonesian and regional languages in Indonesia, as well as difficulties in English language skills and English linguistics.

Studying abroad certainly offers its own challenges for foreign students. They argue the challenges they face are living independently, self-confidence, and adapting to the environment like food, language, or culture.

An interview with an English lecturer at Islamic Universities and College in Kalimantan showed that foreign students from neighboring countries, especially Malaysia and Thailand were quite interested in education in Indonesia, becoming English language students in Indonesia and giving them a lot of experience. An experience that is not only valuable to students but also to lecturers from the aspect of learning English and improving the quality of future English lectures.

Relating to the beliefs and reasons for foreign students studying at Islamic Universities and College in Kalimantan, lecturer respondents gave the following response.

Lecturer A answered:

"They received an educational scholarship from campus and proud to study abroad (Indonesia)."

Lecturer B said:

"In my opinion, they chose to study in Indonesia, especially at one of Islamic Universities and College in Kalimantan due for several reasons. First, they are interested in learning the culture of the local area. Secondly, they assume that education in Indonesia is better than education in their own country."

Lecturer C declared:

"Description of activities which is interesting and is complemented by achievements and outputs from the program interest the foreign 
students to enroll here. The program is wrapped with various activities such as cultural trips or cultural exchange on campus."

Lecturer D argued:

"Kalimantan has the prospect of rapid socio-economic development, being the nation's capital will greatly support the advancement of education. For foreign students, this has become an attraction because of the sharing of facilities and advancing social economy."

Indonesia, as a country where English stills a foreign language, English becomes an unfamiliar language for its people. In the process of learning English, the presence of native speakers becomes important. Regarding this issue, there should be native speakers in English language lectures, the English lecturer of Islamic Universities and College in Kalimantan gave the following response.

Lecturer A stated:

"Yes, there must be. Here, in Palangkaraya, there is a native teacher from RELO (running for the second year)."

Lecturer B perceived:

"Not necessarily but it is important to consider because the typical characteristics of Indonesian people are really exciting when meeting strangers or foreigners, and so too when the students are taught by foreigners. I'm sure their motivation will increase if sometimes foreign teachers are invited to join teaching here, especially in language classes. In addition, it is a good way to learn speaking directly through native speakers."

Lecturer D appended:

"Need to be an icon to create a supportive environment."

Ideally lectures in English use 100\% full English without any other language. But often, it is rather difficult to practice with several different considerations depending on how to deal with it. In connection with this issue, whether to use $100 \%$ full English or not in the process of lecturing English, here are the answers to the lecturers.

Lecturer B argued:

"Should be, or at least 50 percent use of foreign languages in the learning process, especially in language classes. It is intended that students are not only able to master the theory but they can practice it at least in the classroom as 'practice makes perfect." 
Umar Fauzan and Nadia

Lecturer D realized:

"For students from Asia it might be 50\% but for European students should be full English, consideration of the context where the speakers from."

Foreign students studying in Indonesia certainly will not always easy and will experience some difficulties. The main difficulties faced by foreign students studying English in Indonesia (Kalimantan) are as described in the following responses from lecturers:

Lecturer B commented:

"Based on what I saw in class when learning took place, foreign students, especially Thai students mostly prefer to keep silent, tend to be passive in the classroom. My opinion is why they tend to be passive in class because of 'language', 'anxiety' 'culture diversity' etc. In terms of language, Thai students sometimes cannot get material perfectly especially if the lecturer uses 'full English' language. On the other hand, they have also revealed that basically they understand but do not dare to vote because they are embarrassed, afraid of being wrong, and feel the ability of Indonesian students (IAIN Samarinda is much better than them. For the solution, one of them said it is better to use 'mix-language' in the learning process that is Indonesian and English."

\subsection{Observation Results}

Observations were made by visiting directly to State Islamic University and Islamic institutes in Kalimantan to find some data, relating to learning facilities, a life of foreign students, foreign student interaction, and the English ability of foreign students.

The researcher visited the study site on 14 April until 25 June 2019. From the visits, it was obtained several important notes relating to foreign students at Islamic University and Islamic institutes in Kalimantan.

First, learning facilities, in general, are good. Islamic Higher Education in Kalimantan has complete facilities and infrastructure to support the process of teaching and learning English. The facilities provided are study rooms, libraries, reference books, open places for discussion, textbooks. For internet access, all Islamic Higher Educations in Kalimantan have prepared free internet access for all campus civitas, although sometimes internet access is slow due to many users accessing the internet at the same time. For the room convenience, not all lecture rooms are equipped with air conditioning (AC), there are some limited rooms that are equipped with $\mathrm{AC}$, while the other room only use fans. For native speakers, the 
State Islamic University of Antasari and State Islamic Institute of Palangkaraya have native speakers to support learning English.

Second, the learning process is varies depending on each subject. Lectures carried out with a variety of teaching methods and techniques as well as the use of instructional media. In speaking classes, various teaching methods are applied to encourage students to be active and increase their English skills, such as: conversations, games, projects, drama, speeches, debates, presentations and so on. On other subjects, interesting and varied learning is also applied; games, discussions, presentations, projects, outside class learning, etc. The media also varies from pictures, videos, social media, as well as e-learning such as Edmodo and moodle. It can also be seen from direct observations that not all foreign students are active in English class, only one or two appear active, while others appear unenthusiastic and inactive. There appear to be issues of self-confidence or adaptation issues for some foreign students.

Third, the interaction of foreign students is relatively different from that of every foreign student. Some of them seem to be able to get along easily with people and the lives of students from Indonesia, but there are also those who seem closed and sociable only in the community of foreign students. However, that only happens outside the classroom, if in the classroom all students, both foreign and non-foreign, can interact properly.

An interesting note from the interaction of these foreign students is that some of the students are rather fluent in Indonesian, but some others are unassertive and unwilling to participate in conversations using Indonesian. The atmosphere is more open and lively when they chat with friends who come from the same country. Language seems to be an obstacle for some foreign students.

Fourth, the English proficiency of foreign students studying English in Kalimantan is quite diverse; some are ordinary but some are very good. The researcher conducted direct observations by conversing with foreign students using English. The result was some of their ability was not bad while some others are very good by giving lengthy explanations in English with considerable confidence. In general, their learning outcomes are not too disappointing.

\subsection{Documents Review Results}

Documentation was collected as a check and re-check material from the results of research using interviews and observation instruments. Review documentation to strengthen the research findings that have been carried out using other instruments. The examined documentation includes: Law No. 12 of 2012 concerning Higher Education, Classification of Indonesian Higher Education RISTEKDIKTI 2019, Guide to The Preparation of The Self Evaluation Reports of Higher Education Accreditation, Guide to The Preparation of The Self Evaluation Reports of Study 
Programs Accreditation, Curriculum, Lesson Plan, Midterm Questions, and Final Exam Questions.

The results of the documentation show that each Higher Education should attract foreign students in order to demonstrate institutional quality. If higher education has foreign students, it can be assigned better institution than the other one. For this reason, the government has tried to attract foreign students through various policies.

In-Law No. 12 of 2012 concerning Higher Education in article 75 stated that foreign citizens can become students at higher educations in Indonesia. Through this law, foreigners are guaranteed by the Laws of the Republic of Indonesia to become students in Indonesia. The government is opening the door for the internationalization of higher education in Indonesia by inviting as many foreigners to register and study in Indonesia.

Not only giving freedom to universities to accept foreign students, but the government also includes one of the indicators that the more the presence and number of foreign students in higher education in Indonesia the more the higher ranking of institutions will get. This challenge is offered by the Indonesian Ministry of Research, Technology, and Higher Education. This provision can be seen in the document "Classification of the Indonesian Ministry of Research, Technology, and Higher Education 2019" issued by the Indonesian Ministry of Research, Technology, and Higher Education.

The importance of contributing the presence of foreign students in a university can also be evidenced from the document "Guide to The Preparation of The Self Evaluation Reports of Higher Education Accreditation and Guide to The Preparation of The Self Evaluation Reports of Study Programs Accreditation" which state that one of the points that must be assessed and increase the value in calculating the score of accreditation is the presence and number of foreign students owned by a higher education or a study program in a higher education.

From the aspect of rules, the presence of foreign students is an inevitable necessity. Thus, universities in Indonesia, including religious higher education, try to attract foreign students to Indonesia. In its development, there are a number of foreign students from Malaysia, Thailand, and Turkey studying in English language study programs at Islamic Higher Education in Kalimantan.

Increasing foreign students requires serious attention from the aspect of organizing an English study program. From the documentation, the English language education study programs at Islamic Higher Educations in Kalimantan use the National Qualification Framework curriculum (KKNI) which targets the success of learning through formulated learning outcomes. In practice, as part of planning lectures, lecturers who teach English make lesson plans to ensure the learning process is appropriate with the targets determined. It can be seen from the developed lesson plan, the lecturers applied various methods to succeed in the lecture process while 
remaining consistent with the material prepared appropriately to the learning outcomes outlined. In the middle and end of the lecture, English lecturers evaluate through the Midterm and Final Exams.

\section{DISCUSSION}

The more foreign students in an English language education study program at higher education, the more it shows the quality of higher education. This is because qualified universities are able to attract and encourage many people to enroll and study at college. Realizing this, the government of the Republic of Indonesia has issued a rule that higher education in Indonesia can be foreign students (Law No. 12 of 2012), one of the indicators of the preparation of the best higher education ranking is the presence of foreign students (Clustering of Indonesian Higher Education by the Indonesian Ministry of Research, Technology, and Higher Education (RISTEK-DIKTI) 2019), to the management of study programs and universities based on accreditation also includes indicators of the presence of students as one of the assessment points (Guide to The Preparation of The Self Evaluation Reports of Higher Education Accreditation and Guide to The Preparation of The Self Evaluation Reports of Study Programs Accreditation).

Following the government's policy, Islamic Higher Education through the Ministry of Religious Affairs (http://diktis.kemenag.go.id) has also prepared strategic steps to implement the policy. The policy is to create a program of 5000 foreign students which began in 2018 and is expected to get 1,000 foreign students entering Indonesia every year.

The findings of this study indicate that Indonesia's socio-cultural prosperity is one of the attractions of students to continue studying besides the belief of the students themselves. This finding is consistent with the opinion of Isabelli-García \& Isabelli, 2019) which states that when it comes to foreign student lectures, there are 2 main things that are the focus of attention, namely language development, and sociocultural benefits. Although of course, language development and socio-cultural benefits will not be obtained by foreign students if they are not sure to register and go to Indonesia to continue their studies in the field of English language education. There are many foreign students enroll and study at English language study programs in Kalimantan. It means that they are believed to those programs as the success of learning English is determined by their beliefs. In line with this, Nhapulo (2013) said, “There is a need for creating an environment in which teachers' and learners' cultural background, beliefs and needs are considered so as to enable teachers to teach effectively, as well as enabling learners to achieve positive learning outcomes."

The English curriculum is a reason to believe in studying in English. They believe that the curriculum used is appropriate, carried out in a good process, facilitated by adequate learning facilities, and implemented by competent teachers with good 
learning methods. Therefore, it is necessary to ensure that all of these are prepared and improved by the management of English language study programs. This becomes important, as it is described by Briggs (2015), "Study Abroad curricula of guidance for learners on how to plan, manage and manipulate informal language contact for maximum linguistic gain."

Foreign students believe that if they study in Kalimantan, they will get the additional benefit of not only learning English but also studying Islamic material. In addition, they are likely to have different experiences studying abroad and learn more about the richness of the tribes, cultures, and languages that exist in Indonesia. Foreign students studying English in Kalimantan not only get English language learning but also socio-cultural benefits include an Islamic atmosphere as one from many reasons for studying outside the country (Isabelli-García \& Isabelli, 2019).

Maintaining and fostering the belief of foreign students to study English in Islamic Higher Education in Kalimantan is important because these beliefs affect the learning of English students. Kaymakamoğlu \& Atmaca (2016) points out that learners' belief affect the actual performance of people in the area that the learning takes place. On the other side, Abdi \& Asadi (2015) agree that students' beliefs affect their motivation, attitude, achievement, proficiency, anxiety, success, behavior and language learning strategy use. Some of these beliefs are positive and some of them are negative. The negative beliefs should be eliminated because they are detrimental to language learning.

Valuable experience gained by foreign students when studying in Indonesia is that at first there were obstacles in Indonesian or regional languages in Kalimantan, later in their development they got additional mastery of the language, had more Indonesian friends who were friendly and fond of helping, valuable knowledge, added experience of life by learning the social life of Indonesian people who enriched their life experiences. This is consistent with Yoshii's research findings (2016) that studying in a foreign country not only learns language but also learns to interact with other cultures that grant the process of learning to respect the perspectives and habits of other people who may be different from our point of view.

In the context of learning English, they learn English material and feel more confident in speaking English. In the future, they will implement the knowledge they have gained in their respective countries. This finding is similar to the findings of Sato (2014) where learning experiences in foreign countries lead students to actively learn English and interact using English which fosters an attitude of adaptation and confidence in the surrounding environment. The findings of this study are also in line with the findings of Song's research (2016) that in this globalization era, the experience of learning English in a foreign country can be applied when returning to one's own country and applying the teaching methods that have been obtained. 
The challenges they faced were living independently, increasing self-confidence, mastering learning material, increasing English speaking skills, and adapting to the environment such as food, language, or culture. This finding is similar to the research findings of Kaypak \& Ortaçtepe (2014) who found that there is a reciprocal relationship between their belief in learning English abroad with the perception of the experience they gained when they registered abroad. At first, students focused more on language accuracy but changed towards communicating language functions which helped them try harder to achieve their English learning goals.

Considering the fact that not all foreign students have good English skills, thus this has become a challenge to foreign students who study English and to lecturers who teach English. A cultural approach is needed to address these challenges, such as what Fang \& Baker (2018) stated, "More in-depth and critical approaches to teaching language, culture and intercultural communication in ELT are needed which foster and cultivate students' sense of intercultural citizenship."

\section{CONCLUSION}

From the research findings and discussion in the previous section, the following conclusions can be deduced. First, foreign students believe in English language education in English language study programs at the Islamic Higher Education in Kalimantan. They accept as true that the curriculum used is appropriate, carried out in a good process, facilitated by adequate learning facilities, and implemented by competent teachers with varied learning methods. They are also assured to get the extra benefit of not only learning English but also learning Islamic material. So, all of that needs to be ascertained, prepared, and enhanced by the management of English language study programs in Islamic Higher Education in Kalimantan. Second, regarding the experience of foreign students, there are two main things need to be taken into account namely language development and socio-cultural benefits. In the context of learning English, they learned English material and felt more confident in speaking English but from the socio-cultural aspect, foreign students enhanced life experiences by learning the social life of the Indonesian people who enrich their life experiences. Third, the challenges they faced were independent living, increasing self-confidence, mastering learning material, improving English speaking skills, and adapting to the environment like food, language, or culture.

\section{REFERENCES}

Abdi, H., \& Asadi, B. (2015). A Synopsis of Researches on Teachers' and Students' Beliefs about Language Learning. International Journal on Studies in English Language and Literature, 3(4), 11.

Altan, M. X. (2006). Beliefs about Language Learning of Foreign Language- Major University Students. Australian Journal of Teacher Education, 31(2). https://doi.org/10.14221/ajte.2006v31n2.5 
Umar Fauzan and Nadia

Briggs, J. G. (2015). Out-of-class Language Contact and Vocabulary Gain in a Study Abroad Context. System, 53, 129-140. https://doi.org/10.1016/j.system.2015.07.007

Fang, F. (Gabriel), \& Baker, W. (2018). 'A more Inclusive Mind towards the World': English Language Teaching and Study Abroad in China from Intercultural Citizenship and English as a Lingua Franca Perspectives. Language Teaching Research, 22(5), 608-624. https://doi.org/10.1177/1362168817718574

Isabelli-García, C. L., \& Isabelli, C. A. (2019). What Is the Impact of Study Abroad on Interlanguage? in C. L. Isabelli-García \& C. A. Isabelli (Ed.), Researching Second Language Acquisition in the Study Abroad Learning Environment: An Introduction for Student Researchers (p. 65-96). Springer International Publishing. https://doi.org/10.1007/978-3-030-25157-4_4

Kaymakamoğlu, S., \& Atmaca, M. (2016). Learner Beliefs in Language Learning: A Study on the Effects of Context In Learners' Perception. International Journal of New Trends in Arts, Sports \& Science Education (IJTASE), 5(2). http://www.ijtase.net/ojs/index.php/IJTASE/article/view/480

Kaypak, E., \& Ortaçtepe, D. (2014). Language Learner Beliefs and Study Abroad: A Study on English as a Lingua Franca (ELF). System, 42(1), 355-367. https://doi.org/10.1016/j.system.2014.01.005

Miles, M. B., \& Huberman, A. M. (1994). Miles, M. B., \& Huberman, A. M. (1994). Qualitative Data Analysis: An Expanded Sourcebook. Thousand Oaks, CA: Sage Publications. SAGE Publications.

Morreale, S. G. (2011). The Relationship Between Study Abroad And Motivation, Attitude And Anxiety In University Students Learning A Foreign Language [Dissertations]. Wayne State University.

Nhapulo, M. A. (2013). Teacher and learner beliefs and expectations about English language teaching and learning at a Mozambican university. Afrika Focus, 26(2). https://doi.org/10.21825/af.v26i2.4913

Sato, T. (2014). The Effects of Study Abroad on Second Language Identities and Language Learning. Turkish Online Journal of Qualitative Inquiry, 5(3). https://doi.org/10.17569/tojqi.56715

Song, J. (2016). (Il)Legitimate Language Skills and Membership: English Teachers' Perspectives on Early (English) Study Abroad Returnees in EFL Classrooms. TESOL Journal, 7(1), 203-226. https://doi.org/10.1002/tesj.203

Tanaka, K., \& Ellis, R. (2003). Study-abroad, Language Proficiency, and Learner Beliefs about Language Learning. 25(1), 23.

Yoshii, H. (2016). Japanese Students' Reconceptualization of Racialized English and English Speakers through Study Abroad. University of British Columbia. 